JOANNA BIGOS

ORCID: 0000-0001-8703-4446

Uniwersytet Wrocławski

joanna.bigos2@uwr.edu.pl

ANNA MACIĄG

ORCID: 0000-0002-1741-1653

Uniwersytet Wrocławski anna.maciag@uwr.edu.pl

\title{
Sprawozdanie z uroczystości jubileuszu pięćdziesięciolecia Instytutu Nauk Administracyjnych Wydziału Prawa, Administracji i Ekonomii Uniwersytetu Wrocławskiego - „Niepomijalność administracji publicznej” (Wrocław, 7 czerwca 2019 roku)
}

Uniwersytet to wspólnota służących rozwojowi ludzi i ich myśli. To przestrzeń spotkania przedstawicieli różnych pokoleń dążących do mądrości i dzielących się pasją, zorientowanych na odkrywanie prawdy i służbę społecznościom. Uniwersytet to obcowanie Mistrzów i Uczniów zorganizowanych w określonej strukturze. Jednym z elementów struktury Uniwersytetu Wrocławskiego jest istniejący w ramach Wydziału Prawa, Administracji i Ekonomii Instytut Nauk Administracyjnych, który 7 czerwca 2019 roku obchodził pięćdziesięciolecie istnienia. Uroczystość ta była wyjątkowym wydarzeniem, łączącym w sobie to, co dla Instytutu charakterystyczne: merytoryczną dyskusję i refleksję zorientowaną na człowieka. Jak powiedział prof. dr hab. Jan Jeżewski - „Było to zdarzenie ustrojowe o wielkim znaczeniu emocjonalnym dla wielu". 
Obchody jubileuszu rozpoczęły dźwięki Gaudeamus igitur wykonanego na żywo przez skrzypaczki z Akademii Muzycznej im. Karola Lipińskiego we Wrocławiu. Następnie otwarcia jubileuszowej konferencji dokonał dyrektor Instytutu Nauk Administracyjnych dr hab. Tadeusz Kocowski, prof. nadzw. UWr. W tym ważnym dla wszystkich pracowników i doktorantów Instytutu dniu swoją obecnością zaszczycili przedstawiciele władz Uniwersytetu Wrocławskiego, a także byli dyrektorzy Instytutu Nauk Administracyjnych oraz reprezentanci środowisk związanych z Instytutem - miasta Wrocławia, Wojewódzkiego Sądu Administracyjnego we Wrocławiu, Państwowej Straży Pożarnej we Wrocławiu oraz Stowarzyszenia Absolwentów Wydziału Prawa, Administracji i Ekonomii. Z okazji jubileuszu do Wrocławia przyjechali przedstawiciele różnych ośrodków akademickich z całej Polski. W sali imienia prof. Witolda Świdy obecni byli również emerytowani pracownicy INA, a także członkowie rodzin zmarłych pracowników.

$\mathrm{Na}$ wstępie dyrektor Instytutu Nauk Administracyjnych przybliżył historię Instytutu powstałego w 1969 roku dzięki staraniom profesorów dr. hab. Franciszka Longchamps de Bérier i Tadeusza Bigo. Profesor Kocowski wskazał, że po pięćdziesięciu latach od powstania Instytut zatrudnia dwudziestu dziewięciu pracowników naukowych: pięciu profesorów tytularnych, pięciu profesorów nadzwyczajnych, jednego doktora habilitowanego, siedemnastu adiunktów, jednego asystenta oraz pracownika sekretariatu Instytutu. Od momentu powstania Instytut może poszczycić się przeprowadzeniem dwudziestu dziewięciu przewodów habilitacyjnych, stu dwudziestu jeden postępowań doktorskich; obecnie studia doktoranckie w ramach Instytutu odbywa pięćdziesięciu doktorantów. Dyrektor zaznaczył, że Instytut w dzisiejszym kształcie i z obecnymi sukcesami nie istniałby, gdyby nie praca kilku pokoleń uczonych. Pamięć tych, którzy odeszli, uczczono minutą ciszy.

W początkowej części spotkania głos zabrali zaproszeni goście. Jako pierwszy przemówił Rektor UWr, który podkreślił istotę zdarzeń przeszłych wobec kształtowania współczesności i zachęcał, aby pamięć o początkach Instytutu była zachowywana i w dalszym ciągu pielęgnowana. Gratulacje i podziękowania za dotychczasową współpracę złożyli także przedstawiciele Prezydenta Wrocławia oraz Państwowej Straży Pożarnej we Wrocławiu. Zabierający głos zwracali uwagę na zaangażowanie pracowników Instytutu w lokalną i ogólnopaństwową współpracę na rzecz funkcjonowania i rozwoju administracji publicznej i realizacji idei dobra wspólnego. Tę część jubileuszowej konferencji zakończyło wystąpienie skarbnika Stowarzyszenia Absolwentów Wydziału Prawa, Administracji i Ekonomii „Uniwersytecka”.

Po wystąpieniach zaproszonych gości prof. Tadeusz Kocowski kontynuował instytutowe reminiscencje, zwracając uwagę na to, że działalność jego pracowników nie zamyka się w murach Uniwersytetu. Egzemplifikując, wskazał chociażby na prof. dr. hab. Marka Mazurkiewicza, który był przewodniczącym komisji konstytucyjnej, prof. dr. hab. Leona Kieresa, który zasiadał w Trybunale Konsty- 
tucyjnym oraz kierował Instytutem Pamięci Narodowej. Prof. Kocowski podkreślił również zaangażowanie pracowników Instytutu w praktykę administrowania, powołując się na przykłady ich członkostwa w samorządowych kolegiach odwoławczych, czy też pełnienia funkcji sędziów sądów administracyjnych — zarówno wojewódzkich sądów administracyjnych, jak i Naczelnego Sądu Administracyjnego. Kończąc tę wypowiedź, prof. Kocowski podkreślił, że mocną i ważną stroną od początku istnienia Instytutu jest dobra atmosfera i koleżeńska postawa.

Jako kolejny w tej części jubileuszu głos zabrał dziekan WPAE, prof. Karol Kiczka. W swojej mowie odwoływał się do wspomnień o profesorach, których poznawał w czasie studiów na Wydziale, a którzy tworzyli Instytut Nauk Administracyjnych. Zaznaczył również istotę wspaniałej atmosfery, przywołując do dziś aktualne słowa prof. Jana Jendrośki - „Trzymajmy się razem”.

Kolejna część obrad oddzielona została od oficjalnego rozpoczęcia wykonaniem trzech utworów skomponowanych przez Johannesa Brahmsa, który w 1879 roku został uhonorowany przez Senat Uniwersytetu Wrocławskiego tytułem doktor honoris causa UWr. Następnie zgromadzeni goście mogli obejrzeć prezentację multimedialną przygotowaną przez przedstawicieli młodszego pokolenia pracowników ze zdjęciami upamiętniającymi życie Instytutu w trakcie ostatnich pięćdziesięciu lat.

Merytoryczną część konferencji rozpoczął wykład ks. prof. dr. hab. Franciszka Longchamps de Bérier. Nawiązał on do naukowych osiągnięć swojego dziadka, prof. Franciszka Longchamps, wybitnego komparatysty i ojca założyciela Instytutu Nauk Administracyjnych. Wspominał, że obszarem naukowych badań prof. Franciszka Longchamps de Bérier, aż do ostatnich chwil życia, były głównie: wolności oraz człowiek jako podmiot prawa i sens działania organów administracji publicznej. Prelegent wskazywał, że prof. Franciszek Longchamps de Bérier pozostawił nam konkretne przesłanie, aby w badaniach nad prawem administracyjnym nie odwracać się od wartości. W czasie swojego wystąpienia sformułował pytania, wokół których prowadził dalsze rozważania - co pozostawia po sobie akademik: czy jest to dzieło naukowe, jego uczniowie czy może stworzone instytucje. Związane z tym refleksje dotyczyły uniwersyteckiego dziedzictwa prof. Franciszka Longchamps de Bérier, prowadząc do konkluzji wskazującej na istotne znaczenie genealogii uniwersyteckiej, wpływu naszych mistrzów, znaczenie naukowej tożsamości. Myśl, pomysł, sposób i styl uprawiania nauki to elementy, które akademicko dziedziczymy, z którymi się konfrontujemy i dzięki temu wspólnie poszukujemy mądrości. Ksiądz profesor wskazał, że mistrza powinna charakteryzować wrażliwość, tak aby uczniowie mogli się na nim wzorować. Dobrego naukowca cechować będzie także wybór uczniów, którzy będą od niego lepsi. Kolejną postawioną w wykładzie kwestią było koleżeństwo w zespole i otwarte pytanie o to, jak je osiągnąć. Jako istotne dla uniwersyteckiego warsztatu wskazano również znajomość języków obcych, koncentrację na dziele, a nie na sobie, oraz szczere otwarcie badawcze. Franciszek Longchamps de Bérier 
wskazał też na potrzebę podejmowania tematów ważnych, zasadniczych, podstawowych, interdyscyplinarnych i aktualnych. Konkludując, podkreślił, że meritum badań niewątpliwie powinien być człowiek i humanistyczny sens działania organów administracji publicznej.

Kolejną część spotkania słowami: „Instytut tkwi w moim sercu i moim umyśle" rozpoczął prof. Leon Kieres, pełniący funkcję moderatora. W swoim wystąpieniu profesor powrócił do wspomnień o prof. Longchamps de Bérier, jego oddaniu nauce i studentom, pasji oraz naturalnej dobroci. Następnie wspomnieniami ze zgromadzonymi podzielił się prof. Jan Jeżewski, który powrócił do początków pracy w Instytucie, budowania od podstaw koncepcji przedmiotu „nauka organizacji i zarządzania” oraz wspominał naukowe dyskusje z profesorami Bigo i Longchamps de Bérier na temat tego, czym właściwie jest nauka administracji. Tadeusz Bigo wspomniany został również przez dr. hab. Józefa Koredczuka, prof. nadzw. UWr, który przedstawił go jako człowieka, który całe życie poświęcił Instytutowi - najpierw we Lwowie, a następnie we Wrocławiu. Był założycielem i współtwórcą wrocławskiej szkoły nauki prawa administracyjnego, nauczycielem-badaczem o szerokim horyzoncie wiedzy, twórczym i precyzyjnym sposobie myślenia oraz wielkim sercu. Profesor Koredczuk zwrócił uwagę na obecną od zawsze w Instytucie dobrą atmosferę. Wspominał prof. Jendrośkę, który wpoił swoim uczniom nie tylko zamiłowanie nauki, lecz także metody pracy; prof. Bigo zaś spokojne spojrzenie. Do swoich współpracowników mówił: „Nigdy się nie denerwuj bez względu na to, co powie i jak się zachowa student, nie szczędźcie czasu, nie spiesz się na egzaminie, bo to jedyny czas poznania tego, co myśli student". Profesor Barbara Adamiak z kolei odniosła się do tego, co niepomijalne w prawie administracyjnym. Zaznaczyła, że we wrocławskich badaniach zawsze obecne było zagadnienie prawa jednostki do obrony, a jego ujęcie nigdy nie było formalistyczne — zawsze poszukiwano wartości. Profesor Adamiak wskazała na duży wkład pracowników Instytutu w ustalenia doktryny oraz zaznaczyła ważną pozycję wrocławskiego Instytutu w polskim środowisku naukowym. Pierwszą część spotkania zwieńczono odczytaniem okolicznościowego listu prof. dr. hab. Jana Zimmermanna, który zaznaczył wartość integracji wewnętrznej Instytutu i dziękował za wspólne inicjatywy w dążeniu do zgłębiania nauki prawa administracyjnego oraz za krakowsko-wrocławskie przyjaźnie.

Tematem drugiej części jubileuszowej konferencji uczyniono dydaktykę, a także powiązane $\mathrm{z}$ nią zagadnienie studenckiego „ducha naukowego". Jako pierwsza zabrała głos dr Barbara Kowalczyk - moderator dyskusji tej części spotkania — zaznaczając, że Instytut Nauk Administracyjnych ma zasługi i osiągnięcia w nauczaniu. Ponad sto prowadzonych przedmiotów, wysoko oceniane studia na kierunku administracja, zorientowanie działań na studenta, świadczą o znacznym rozwoju Instytutu w ciągu pięćdziesięciu lat funkcjonowania. Następnie prof. Stanisław Sagan powrócił do korzeni Instytutu. Metaforą wspomnienia uczynił pojęcie drogi, które — jak wskazywał — definiowane jest na co najmniej 
kilkadziesiąt sposobów. Profesor zauważył, że życiowe ścieżki ludzi bywają „,poplątane"; wskazywał, że to między innymi przez pychę, wielość przyjmowanych postaw, niewiedzę czy naiwność schodzi się z właściwej drogi. $Z$ drugiej jednak strony dodał, że to właśnie dzięki tej niebezpiecznej, budzącej lęk i niepokój wędrówce ludzie się do siebie zbliżają, integrują, a z czasem oferują wsparcie, by wspólnie podążać wspólnym szlakiem. Ta metaforyczna część wypowiedzi podsumowana została porównaniem rozwoju Instytutu Nauk Administracyjnych do archetypu drogi, czyli wędrówki do Kanaanu, choć ta pierwsza trwa już o dekadę dłużej. Droga naukowa we wspomnieniach Profesora miała swój najlepszy, najbardziej twórczy okres właśnie na Uniwersytecie Wrocławskim, gdzie miał możliwość nauki od mistrzów - prof. Adama Chełmońskiego, prof. Jana Jeżewskiego; tu ukształtował siebie jako człowieka.

Drugie wystąpienie miało wymiar historyczny. Absolwent studiów na kierunku ,administracja”, mgr Stanisław Stępień, przeniósł się wspomnieniami do początków studiów, kiedy jako jeden z pierwszych miał okazję studiować na kierunku o takim profilu. Okoliczności nie były bardzo sprzyjające, ponieważ oferta skierowana została do tych studentów, którzy nie dostali się na prawo. Pytań było wiele; początkowo nie był znany program studiów ani ich cel. Pojawiło się poczucie bycia gorszym od studentów prawa. Obawy szybko jednak zostały zastąpione zaangażowaniem. Uniwersytet Wrocławski stał się głównym ośrodkiem naukowym kształcącym na kierunku administracja. Jak wskazywał mgr Stępień, zorganizowano trzy konferencje naukowe studentów administracji z całego kraju i obóz naukowy na temat ochrony środowiska dwa lata po konferencji sztokholmskiej ONZ z 1972 roku. Dzięki temu Wydział uzyskał zgodę na prowadzenie studiów magisterskich na kierunku administracja. To był silny rocznik studentów, ponieważ — jak puentował jego absolwent — z blisko sześćdziesięciu studentów, którzy ukończyli studia, sześciu jest już profesorami. Podobnie jak przedmówca jako postaci naukowe, które znacząco ukształtowały jego osobę, wskazał profesorów Adama Chełmońskiego i Jana Jeżewskiego.

By zobrazować upływ czasu, który jedynie rozwija i buduje, w trzecim wystąpieniu głos przekazano studentowi piątego roku studiów Norbertowi Czechowskiemu. W wystąpieniu padły słowa, że mądrości trzeba szukać u mądrych, a jak wskazywał prof. Jan Boć, to ludzie tworzą administrację i są adresatami jej działania, ponieważ w administracji najważniejszy jest człowiek i jego dobro. Na tym fundamencie Czechowski wskazał, że dzięki mądrości kadry budującej i rozwijającej Instytut wszyscy otrzymali podstawy aksjologicznego postrzegania rzeczywistości, kulturę i wychowanie, które mają sprawić, że zawsze będzie się dbać o dydaktykę, w której centrum jest dobro człowieka, a także o relacje, których podstawą jest koleżeństwo.

Tuż po zaplanowanych wystąpieniach głos zabrali uczestnicy jubileuszu. Doktor Andrzej Pakuła z pewnym zaniepokojeniem wskazał na regres rozwoju szkolnictwa wyższego związany chociażby z łączeniem nauki administracji z na- 
ukami politycznymi na wzór amerykańskiego pojmowania administracji, której celem jest traktowanie administracji jako narzędzia władzy, a nie zaspokajanie potrzeb zbiorowości. To — w ocenie dr. Pakuły — jest pominięciem głównej wartości, to jest interesu publicznego w powiązaniu z dobrem wspólnym. Profesor Jerzy Supernat wskazał z kolei na to, że przed Instytutem stoją nowe wyzwania, ponieważ zmieniająca się rzeczywistość powoduje konieczność redefiniowania pojęć podstawowych, jak na przykład pojęcia administracji publicznej, którego obecnie używana definicja jest już za wąska. Głos zabrali również przedstawiciele Katedry Prawa Administracyjnego Uniwersytetu Opolskiego, wspominając profesorów Jana Bocia i Konrada Nowackiego, którym zawdzięczają powstanie i ukształtowanie Katedry. Z przyjemnością wspominali współpracę swojej Katedry Prawa Administracji Uniwersytetu Opolskiego oraz Instytutu Nauk Administracyjnych Uniwersytetu Wrocławskiego, licząc, że będą jeszcze kolejne okazje, by działać wspólnie. Wspomniano również prof. Lidię Klat-Wertelecką jako osobę, której wpływ na rozwój Katedry miał wymiar nie tylko naukowy, lecz także życiowy.

Profesor Kocowski, zamykając jubileusz pięćdziesięciolecia istnienia i funkcjonowania Instytutu Nauk Administracyjnych, życzył wszystkim, by kolejne naukowe pokolenia za pół wieku mogły obchodzić jubileusz stulecia wrocławskiego Instytutu. Zaznaczył bowiem, że młodzi pracownicy i doktoranci Instytutu mają w sobie wiele zapału i zaangażowania do kontynuowania dzieła mistrzów prawa administracyjnego. 